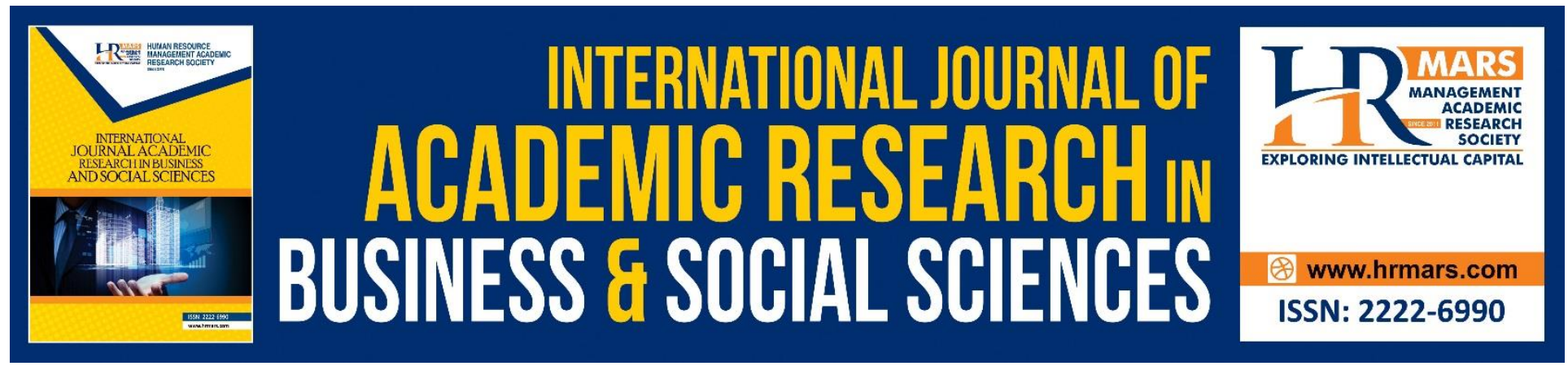

\title{
Perceptions of Stakeholders in Corporate Social Responsibility and Irresponsibility in Tanzania
}

\author{
Ahmad Mtengwa Burhan, Mayasa Mussa Kalinga
}

To Link this Article: http://dx.doi.org/10.6007/IJARBSS/v8-i9/4674

DOI: $\quad 10.6007 /$ IJARBSS/v8-i9/4674

Received: 11 August 2018, Revised: 05 Sept 2018, Accepted: 29 Sept 2018

Published Online: 15 October 2018

In-Text Citation: (Burhan \& Kalinga, 2018)

To Cite this Article: Burhan, A. M., \& Kalinga, M. M. (2018). Perceptions of Stakeholders in Corporate Social Responsibility and Irresponsibility in Tanzania. International Journal of Academic Research in Business and Social Sciences, 8(9), 988-1003.

Copyright: (c) 2018 The Author(s)

Published by Human Resource Management Academic Research Society (www.hrmars.com)

This article is published under the Creative Commons Attribution (CC BY 4.0) license. Anyone may reproduce, distribute, translate and create derivative works of this article (for both commercial and non-commercial purposes), subject to full attribution to the original publication and authors. The full terms of this license may be seen

at: http://creativecommons.org/licences/by/4.0/legalcode

Vol. 8, No. 9, September 2018, Pg. 988 - 1003 http://hrmars.com/index.php/pages/detail/IJARBSS JOURNAL HOMEPAGE

Full Terms \& Conditions of access and use can be found at http://hrmars.com/index.php/pages/detail/publication-ethics 


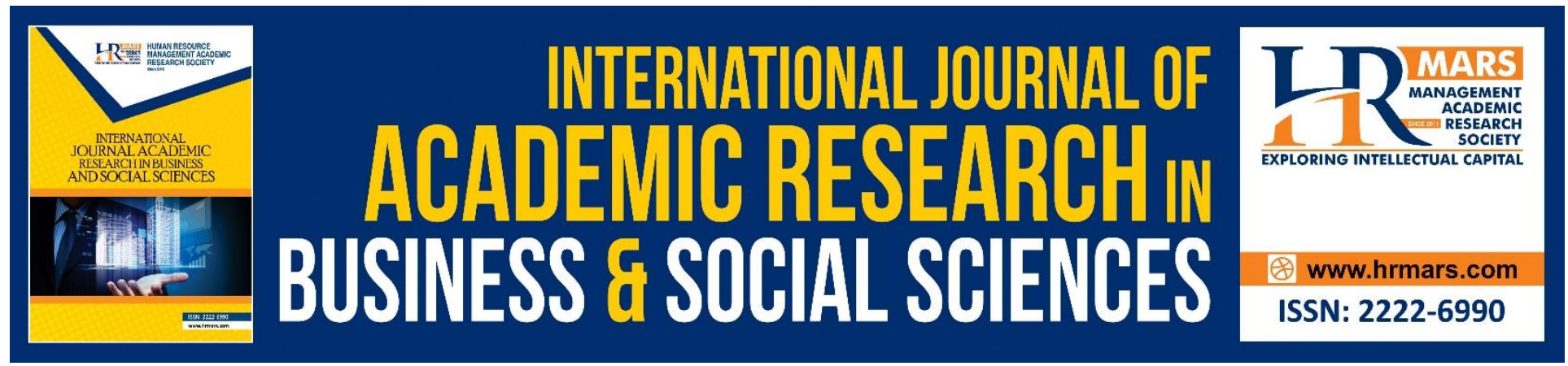

\title{
Perceptions of Stakeholders in Corporate Social Responsibility and Irresponsibility in Tanzania
}

\author{
Dr. Ahmad Mtengwa Burhan \\ Department of Economic Diplomacy, Centre for Foreign Relations \\ Email: mtengwa@hotmail.com \\ Mayasa Mussa Kalinga \\ Department of Economic Diplomacy, Centre for Foreign Relations \\ Email: maya.kalinga@gmail.com
}

\begin{abstract}
For a corporate to survive in a competitive market environment, it must ensure the needs of its stakeholders are given the first priority. Every corporate is obliged to take a responsible part in a community so as to afford a life time existence of its products and the life of its society in general. This can simply be termed as Corporate Social responsibility. It is an obvious fact however, that while most companies have been practicing corporate social responsibility, other companies have been irresponsible to their societies and to the environment surrounding them.

The aim of this study was therefore to understand stakeholders' perceptions, regarding corporate social responsibility and irresponsibility in their societies. Whereas, using an Explorative Factor Analysis study in beverage industries in Tanzania, we found corporate support and corporate geniality is influencing factors for company's social responsibility. While, Corporate Environmental Management and Corporate Safety Management were said to influence corporate social irresponsibility.

This study later recommended on producing socially desirable products and services as the suggested central goal for every company. And second, because moral and environmental pollutions may sometimes be inevitable to abstain, companies were recommended to take responsible compensations if in any case pollutions occurred.
\end{abstract}

\section{Introduction}

\section{Background of the Study}

Businessmen are responsible for the consequences of their actions in a community that covered by their profits and loss. Most corporate and companies have brought lots of problems and hazards that have damaged the community and the environment (Calo, 1974). However, we 
argue that, corporate assume responsibility for addressing these problems and with which it will increase the chances of survival in the future and reduce problems arising within the society concerning the organization.

It is true that, in the business world effective organizations have been striving to survive in a competitive business environment. Through efficient use of factors of production and other facilities from the society, this process of surviving has put companies in a dependent relation with our environment and other stakeholders. As sited by Mullin (2005), the base of this relation is built in a two-way-traffic that is if corporate have to take some from the environment, then stakeholders have to be compensated for what has been taken.

It has been noted that, while some companies try harder to cooperate with the society, others have been running away from their responsibilities within the community (Armstrong, 1977). It is possible that, when business forsakes its responsibilities to the community or creates an intentionally overinflated image of the corporate social responsibility, it is most likely to end up with undesired outcomes. This creates misunderstandings between the community and the corporate.

Moreover, there are some businesses that are said to be continuously involved in the corporate social irresponsibility in the society. These include the auto mobile companies and big oil companies (Kotchen et al, 2011). Most businesses engage in corporate social irresponsibility as an outcome of adapting business practices that do not associate with moral standards of communities surrounding them. This could be in form of child labour, moral pollution and society discrimination. In this essence also, most companies have been a result of disastrous environmental pollution such as emissions of gas and spilling of oil that endanger the lives of people in our communities (Armstrong, 1977).

As noted by William (2010), in his "Stakeholder's Model", the most important entity of any corporate is their stakeholders. These are defined as all those with a "critical eye" on corporate actions (Bownmann-Larsen and Wiggen, 2004), and who are also termed by Freeman (1984), as a group of individuals who are affected by the achievements of organization mission. Corporate should understand that, most of the people in the community are not only investors or consumers, but they are also people who are guided by moral standards and who are affected by the corporate in one way or the other (Pamler and Hartley, 2002). It is therefore the responsibility of corporate to ensure that the needs and interests of multiple stakeholders are met.

The corporate needs to respond to the social responsibilities for two reasons; one is philosophical, where the corporate is needed by the society to take a responsible part in a community along with the locals and other social institutions. The other one is pragmatical, where by the corporate is needed to value the moral standards of the society, or else, its business life will be jeopardized (Parmer et al, 2010).

Corporate Social Responsibility has been a key part of the agenda of many companies that often walk a long way to promote good work (Calo, 1974). It has been a vital strategy for companies to survive in a ruthless market environment, and in enabling them to win the trust and confidence of the people. Recently, the market and customer preferences have become more unpredictable and complex, forcing companies to become directly and constantly involved in the society activities. This includes engaging themselves in programs that have development impact to the 
community. A good example has been shown by Airtel Tanzania in giving scholarships to students so that they can be able to reach their goals.

Although most companies have been trying hard in promoting good moral standards and assisting in community projects, a lot more others have been consequently playing a role of irresponsibility. This has been done through underpaying and overworking company workers, limiting working resources and withdrawing workers incentives such as life and medical insurances. Another one includes spilling of toxic chemicals in the environment as done by most beverage industries which have resulted into spreading of dreadful diseases, birth of disabled children and severe deaths (www.bschool.com).

While most firms in Tanzania have been engaging in corporate social responsibility so as to increase acknowledgement within the society, at the same time they have been creating a distressful environment to the people. This is through noise pollution, air pollution and constant accidents. This in turn puts both questions of responsibility and irresponsibility as vital to their stakeholders.

The study aimed at firstly, exploring the perceptions of stakeholders on the practice of corporate social responsibility and corporate social irresponsibility in the Tanzania beverage industries in particular. It also intended to examine the accuracy and relevance of the assistances and support given out, if in any case correlate to the needs of the societies by Tanzania beverage companies. Secondly, to explore the perception of stakeholders on corporate social irresponsibility practices by beverage companies in Tanzania.

\section{Literature Review}

\section{Corporate Social Responsibility and Irresponsibility}

This means commitment to behave ethically and contribute to economic development while improving the quality of life of our workforce and their families as well as the local community at large (Nexen, 2011). It can be also be defined as a duty of businessmen to follow policies and the ability to make the choices or select those chain of action, which are desirable in terms of objective and value of our society (Bowen, 1953).

In this study, the concept of corporate social responsibility is defined as the involvement of the corporate in the community activities and assisting where there is a need. It also includes adhering to social values of the society that surround the company, and taking accountability of the various actions that destroy the environment and the community at large.

This is a series of actions done by the company that increase extra cost and promote distributional conflict within the community surrounding it (Kotchen et al, 2011). It is a decision to accept other options, which is believed by decision makers to be inferior to the other option when the effects upon all parties are considered (Armstrong, 1977). Armstrong also stated that, the tendency of the top management in the firms to act in their own interest, has often led to social irresponsibility.

In this case, Social irresponsibility can be termed as the tendency of the corporate not to abide with the moral standards set by the community, destruction of the environment and treating of the stakeholder by demolishing them. 


\section{Theoretical Percepective}

There have been a great number of theories explaining the conduct and action of the corporate social responsibility and irresponsibility. Some of these theories include:

Garriga and Mele (2004) noted that, political theories emphasize on social power of corporation. That is any interference between the societies and corporate is a result of power. It should be understood that, power does not only come from within, but also from the outside world (stakeholders). In this aspect, the philosophy behind this theory looks at corporate social responsibility as a source of gaining power in the business environment. Thus, it is very necessary for firms to take responsibilities in their societies as it will give them more authority (Garriga and Mele, 2004).

There are approaches that govern this theory; and one of them is corporate constitionalism. This approach looks at the power in which corporate has within the society and the effect of that power over the society (Davis, 1960). Power of the firm can be handled through "social power equation" or "iron law of responsibility". Whereas in social equation the corporate has power within the society but they have no total responsibility over that society. This is an ideology of free market which emphasizes on no business responsibility towards the society (Davis, 1960).

The iron law of responsibility on the other hand emphasizes on the use of power within the society. Whereas, if one does not utilize the power he has, it will easily be taken away from him. Also, if a firm does not make use of the power that it has in an agreeable way to the moral standards of the society, it will be taken away by other parties in the community.

The second approach is Corporate Citizenship which looks at the firm as a citizen. However, the corporate are not real citizens. But they are regarded as citizens due to the fact that they have the same responsibilities just like the real residents. These include paying taxes, abide with the laws of the society, take part in social activities, follow moral standards and way of living of the society and lastly to be of profit to the society (Caroll, 1979).

Ethical theory focuses on the ethical needs that bind the society and the corporate. It concentrates on the universal principles, codes of conduct and the importance of relation of the corporate social responsibility and sustainable development for the society (Garriga and Mele, 2004). It represents the right things to be done so as to obtain a good society.

The main theories underlying the ethical category include; the Normative Stakeholder Theory, which puts stakeholders as the people with rightful interest in the corporate. The interest of the group in the society is said to be presented in their own sake, and they actually don't further the interests of others such as stockholders (Garriga and Mele, 2004). 
INTERNATIONAL JOURNAL OF ACADEMIC RESEARCH IN BUSINESS AND SOCIAL SCIENCES Vol. 8, No. 9, Sept. 2018, E-ISSN: 2222-6990 @ 2018 HRMARS

There is also the Universal Rights Theory, which is the human rights based approach proposed for the firm to act responsible by the UN Global compact. Corporate are supposed to adhere to human rights labour and environment.

Sustainable Development Theory, which emphasizes on presenting of needs without considering the capacity of the coming generation to obtain their own desires (World Commission on Environment and Development (WCED), 1987). Sustainable development needs to incorporate social environment and economic aspects, so as to balance the long term evaluations in corporate responsibility

Lastly, is the Common Good Approach, which is the classical concept of Aristotelian tradition (Smith, 1999). The theory assumes that, business is the same as any other group found in the society and has to take part in the community. Corporate has to contribute to common good in various ways such as supplying of good and service to the society and participate in well being of the people in a friendly and a peaceful way (Mele, 2002). It should not be seen as a mediating institution (Fort, 1999).

In addition, the most important thing to note is that, there is no common standard of conduct in the world. What might be considered right in a certain country might be wrong in another country a good example are the child labor laws applied in Rwanda and Burundi. Because of the 1994 wars in these two countries, child labor laws had to be minimized to the age of 16 . Thus, the same laws accepted in Rwanda and Burundi is inconsistent with international laws regulating child labor in the world. The same applies in the corporate-society relation that, what might be ethical to the company, might be unethical to the community. This is due to political systems surrounding the relation between the two.

Moreover, values of a firm might also be considered unethical to the community due to the difference in valuing of things within the society. This has made difficulties in assessing relations between groups particularly in understanding each other (Wheenlen et al, 2010).

It assumes that, the firm is an instrument for the increase of the company's profit and that is its main responsibility. It also assumes that the relationship between the society and the company is of economic value. Therefore, it will result to the gaining of wealth (Friedman, 1970). It also assumes that, corporate social responsibility is a means of gaining profit (Garriga and Mele, 2004).

The main approach within instrumental theories is Maximizing of Shareholders' Profit. Wheenlen and Hunger, (2010), argued that, as a human being needs food to survive, so does the firm needs profit to survive and develop. Therefore, maximization of profit is like maximizing food, although, maximizing profit cannot be the main responsibility of the company.

Is a neoclassical economic view which insists on the actions of the corporate and their negative impact to the society when a firm acts responsible, either by maximizing profit or by fighting environmental pollution, there is still a possibility of harming the society. The firm's motive of doing a favor to the society is always drove by several hidden motives inside the firm. Thus, the 
firm will always be likely to face more charges in the society under which its solutions will also be harming the society (Wheenlen et al, 2010). Therefore, the main and only aim of the firm in the society is believed to be creation of profit (Wood and Jones, 1995).

This argued that the corporate has mainly four responsibilities. The first one is to create profit, secondly is to follow the laws of the country. It is said that a company that has tendencies of breaking the law, is likely to gain less from the society (Baucus and Baucus 1997). The third one is social responsibility. This can be classified into two main categories, namely, the philanthropic responsibility and the ethical responsibility. Whereas, the former engages in activities that the society have not yet decided, and the later is concerned with the values and moral standards of the society. It should be remembered that each responsibility is taken into account only if the previous has been fulfilled (Wheenlen et al, 2010).

Table 2.1 Responsibilities of the corporate

\begin{tabular}{|l|l|l|l|}
\hline $\begin{array}{l}\text { Economic } \\
\text { (Must do })\end{array}$ & $\begin{array}{l}\text { Legal } \\
\text { (Have to do })\end{array}$ & $\begin{array}{l}\text { Ethical } \\
\text { (should do })\end{array}$ & $\begin{array}{l}\text { Discretionary } \\
\text { (Might do ) }\end{array}$ \\
\hline
\end{tabular}

Source: (Wheelen and Hunger, 2010)

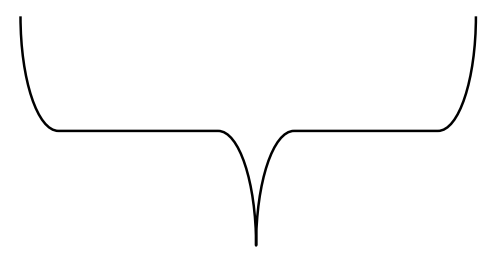

Social Responsibility

O'Riordan and Fairbrass (2008), has called the corporate stakeholder as a "critical eye". This part of a group of people in the corporate, if not well taken care of, they might cause loss or closure of the company. These can be either formal individuals or a collective group that have the ability to affect the company in a positive or a negative way (Murray and Vogel, 1997). In a more critical manner, stakeholders are much involved with the organizational success and operations of the day to day activities of the company.

Stakeholders have been classified into two groups which are Primary and Secondary stakeholders. Primary stakeholders represent those who have a closer relationship with the company and the have high bargaining power (Woods and Jones, 2004). These include customers, creditors, shareholders, employees and suppliers. These stakeholders have the ability to affect the firm in a negative and positive way. It is the task of the firm therefore to understand how the minds of this category of stakeholders work. They are also the most valuable resource the company may use in reaching its goals and mission. Failure to abide to the needs of these stakeholders may lead to loss of profit and closure of the company (William, 2010).

Secondary stakeholders on the other hand, represent a category of people who do not have a direct connection with the company. Although this type of stakeholders do not communicate with the company on regular bases (Woods and Jones, 2004), yet, they affect company's ways of conduct within the society, and they are also affected by the company's actions to the 
community. Secondary stakeholders include Non Governmental Organisation (NGO's), local communities, trade associations, governments and competitors (William 2010).

Figure 2.1 managing effectively model

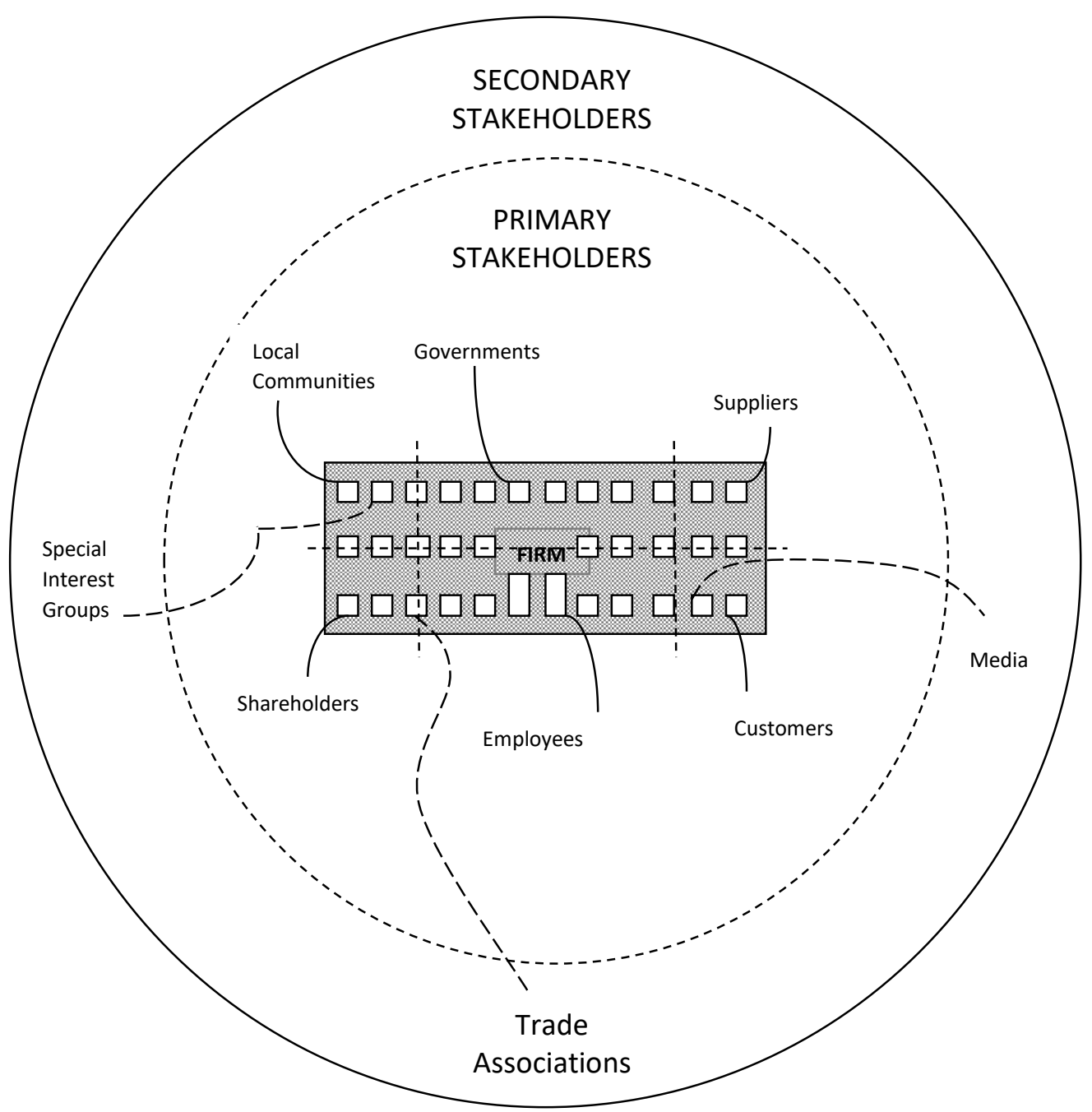

Source: Chuck William (2010). Managing Effectively $4^{\text {th }}$ Ed.

Many studies have measured corporate social responsibility while relating it to the financial matter of the firm. It has been seen that there is a possibility of measuring the relationship of the society and the corporate. Some measures have shown company's aims in dealing with social problems, while others have shown the company's reaction towards social issues such as pollution, poor sewage systems and littering of garbage (Wood and Jones, 1995). However, it has been noted that, companies' awful actions such as oil spill, plane crushes and constant bribery accusations display a terrible firms' image to the society.

In measuring social responsibility, the United States' professor, Donna Wood (2010), explained a framework that involves several levels. The first level explains the responsibility of company 
insisting on the connection between the community and business in a broader perspective. It emphasizes on what is needed by the corporate to the society.

The first level is put under of three major factors which explain the connection between the corporate and the society. These are; legitimacy, which looks at the corporate as one of the social groups in the community. It also explains the relationship and interconnection between the two. Secondly, is the public responsibility which mostly keeps a closer look at the processes and results of a firm to the community. Lastly, is the managerial discretion, under which the managerial and corporate member ethics are put in question. That is, the management has to exercise ethics towards social responsibility (Hopkins, 2004).

The second level explains the processes of responsibility. Corporate social responsibility should involve the ability of the firm to react to social forces. In this way, the firm could survive in the business world. Any corporate needs to understand the environment in which it depends on, but most importantly corporate needs to critically examine the environment, (which is complex) and use the information obtained.

Moreover, there are three considerable elements in this level. These include; scanning of business environment whereas, the corporate gather information in the environment on different matters concerning the company and the society. The second element is shareholder management which mostly defines the boundaries between the connected relation of stakeholders and the corporate and thirdly, the corporate has to listen, find out and sort out societal suggestion, ideas and constraints so as to meet their expected goal and mission. However, the corporate is advised to first define and recognise the main stakeholder of the firm (Hopkins, 2004).

Lastly, is the outcome level which determined whether the corporate social responsibility is making any difference to the society. All stakeholders, however complicating, must be included when measuring corporate performance in the society. Additionally, this level has grouped stakeholders in three categories. The first ones are internal stakeholders who mainly are the people within the companies affecting day to day activities of the firm. Secondly, are external stakeholders who are people outside the firms and who are also affected by the activities of the firms. Lastly, are external institutions which also have an impact to individual firms and to the society at large (Hopkins, 2004).

A beverage is any liquid form that can be consumed by a human being for quenching of thirst or refreshing. It is any potable liquid, especially one other than water as tea, coffee, beer or milk (Dictionary.com). Beverages are classified into sport beverages which help to stay hydrated, healthy and fit. The second group is wine, which is an alcohol made of fumigated fruits juice for enjoyment. Third, is soft drinks which do not contain alcohol. They are carbonate soft drinks which are sweetened with sugar. These include ice tea, soda and squash lemonade. The last group is the flavored drink which is divided into three major groups called natural, organic and artificial drinks. However, beverages in Tanzania are classified into hard and soft drinks. Whereas, the former are the ones which are refreshing and quench thirst and the later are the ones with alcohol in them.

Beverages produced in Tanzania come from companies such as Azam SSB Group, Mohammed Enterprise Limited, Dar es Salaam Distillers, KIBUKU, Coca cola SABCO, Julius Import and Tanzania Breweries Limited. Meanwhile, there are other beverages imported into the country such as Ceres, Delmont juice, Bavaria and Heineken. 
INTERNATIONAL JOURNAL OF ACADEMIC RESEARCH IN BUSINESS AND SOCIAL SCIENCES Vol. 8, No. 9, Sept. 2018, E-ISSN: 2222-6990 @ 2018 HRMARS

Table 2.2 Categories Of Beverages In Tanzania

\begin{tabular}{|l|c|c|}
\hline FIRMS PRODUCT & SOFT DRINKS & HARD DRINKS \\
\hline SBC Tanzania limited & $\checkmark$ & \\
\hline Sayona drink limited & $\checkmark$ & $\checkmark$ \\
\hline Serengeti brewery company & & \\
\hline Mohammed enterprise limited & $\checkmark$ & $\checkmark$ \\
\hline Tanzania distillers limited & & \\
\hline Coca cola SABCO & $\checkmark$ & \\
\hline Bakhresa food product limited & $\checkmark$ & $\checkmark$ \\
\hline Banana investment limited & & $\checkmark$ \\
\hline Tanzania tea packers Itd & $\checkmark$ & \\
\hline East African breweries Itd (Tanzania) & & \\
\hline
\end{tabular}

Source: Developed by Researcher, 2018.

Corporate in Tanzania have been trying to engage themselves in communities, by supporting the needy and underprivileged sectors in the country in aspects of education, health, sports, gender and the environment. The main aim being to increase the standard of living, some efforts have been seen in recent campaigns, such that of breast cancer by the MEWATA, with the help of different financial institutions like Diamond Trust Bank.

There have also been constant engagements of firms in society activities, especially during hazardous times of floods, hunger and famine, bomb blasts and other tragedies that occur in our societies (www.jamiiforum.com). Companies like Azam SSB, IPP Media group and Vodacom Tanzania have been to a greater extent assisting the society by providing them with money and necessary tools needed by the affected society.

While a number of firms in Tanzania have been socially responsible to the societies surrounding them, lots of more others have been intentionally and sometimes without knowing, committing dreadful conducts to the environment. Beverage companies in particular, have been irresponsible in handling waste disposal and in maintaining proper dumping of their plastic bottles. Mobile-advertisements that use trucks, huge speakers with loud music and improperlydressed dancing girls, have also been causing noise pollution and distraction of society values respectively.

\section{Empirical Review}

Despite of being widely researched areas, corporate social responsibility and corporate social irresponsibility still attract more attention and more researches to be done.

Yassin (2016) explored the nature of stakeholders in the corporate social responsibility by showing their relation with businesses. He came up with an argument that, there is need of stakeholders to engage in business organizations. This is due to the fact that, survival of business 
not only depends on the factors of production and other facilities, but also calls for interdependence with the society, governments and the environment at large.

Kemp (2003), who used the mining sector to study corporate-community leadership, outlined the role of participation between NGOs and corporate. For a company to understand social responsibility there should be a hand in hand collaboration with other sectors in the society. Pressures from NGOs determine the fate of externalities and in so doing, firm goals are reached in line with society development. Although this study did not get much attention in Global Resources Companies (GRC), yet it has been so efficient in individual level mining companies Armstrong (1977), in his research on social irresponsibility in management, looked at the act of management in an irresponsible manner to the society. He observed that, the current system of management has been acting in an irresponsible manner within the society. To that end, he proposed possible changes that are likely to reduce the level of irresponsibility in the system.

These researchers however, have not analyzed corporate social responsibility and irresponsibility in Tanzania. They did not show the practices of corporate in the Tanzanian society or on how they get involved in this society. Above all, they did not show peoples' perception on the corporate social responsibility in the community.

\section{Conceptualization of Stakeholders' Perception in Corporate Social Responsibility and Irresponsibility}

These are individuals, group of people or organizations affected by actions of the firms. They have a massive expectation that firms and businesses will act responsibly to the society and the environment at large. In our study, stakeholder was the local communities, customers and employee in the beverage companies. This research aimed at exploring the understanding they have in the conducts of beverage companies in Tanzania.

We aimed to explore company's actions in the community. This includes positive and negative impacts a company has on the environment, customers, employees and the community.

Stakeholders have created images towards companies operating within their societies. Their perceptions towards these companies are based on the practices of individual companies in the societies. An image of company therefore, can either be good or bad depending on how it displays itself in front of its stakeholders. This research intended to explore the image of corporate in the community through activities they engage themselves in.

These are misconducts of the firms in the society. If a company knowingly or unknowingly acts carelessly within the society, its actions may disrupt into chaos and discomfort. A socially irresponsible company can either mistreats its employees, pollute the environment, ignore values of the society or conduct any forms of discrimination.

This is an association of people or individuals with a purpose of making profit. This study intended to explore the actions of the firms toward the society, and how they react towards various responsibilities within the community. 
INTERNATIONAL JOURNAL OF ACADEMIC RESEARCH IN BUSINESS AND SOCIAL SCIENCES

Vol. 8, No. 9, Sept. 2018, E-ISSN: 2222-6990 @ 2018 HRMARS

\section{Methodology}

This research was an exploratory study, as its problem was not well clear and not well researched (Kotler and Armstrong, 2006). We understood how difficult it is to find the exact result or the right answers to our problem, thus, selection of this design was due to the little details available in the corporate social responsibility in Tanzania beverage companies. As a part of an experimental data, this study's population was stakeholders of beverage companies in Tanzania. This study was conducted in Dar es Salaam, Tanzania where most of beverage industries are found. Dar es Salaam is located at $6^{\circ} 48^{\prime}$ South, $39^{\circ} 17^{\prime}$ East and it is one of the commercial cities in the country where most of the beverage companies and stakeholders are found. Companies that were included in this study were Sayona, Tanzania Breweries Limited (TBL) Mohamed Enterprise Limited, Serengeti Breweries Limited (SBL) as to mention but few. This study interviewed 48 respondents (stakeholders) from different areas. That is, 14 employees from beverage industries, 14 customers and 20 people in Dar es Salaam local communities. In exploring the conducts of corporate towards the society, this study used purposive sampling so as to determine stakeholder's perceptions on how they understand corporate social responsibility and irresponsibility. The paper used interview, observation, Focused Group and schedules (Kothari, 2004). In this study, data which involves a one-to-one discussion were collected. This was intended to be used so as to obtain direct access to the necessary information from the respondents. The study used structured questionnaire in a five pointed Likert paper scale, ranging from strongly agree to strongly disagree. This aimed at investigating respondents' perceptions on each variable under investigation. In this study, three stages were involved when analyzing the data. The first one was the multivariate approach, as we aimed at discovering the uncomplicated relationship of pattern between variables. The second one was Correlation analysis that was used to measure the power of determinants of the key variables. And lastly, was the regression stage where we constructed the relationship of the variables. Data collected in this study were reliable as adult respondents and literate respondents were a big part of our data collection process. Thus, this assured collection of information from respondents who were aware of the subject matter. It mostly looks at the instruments that are used and the point to which the measures of the instrument, measures what are supposed to be measured (Leedy and Ormrod, 2001).

\section{Empirical Result and Discussion Variable Description}

This study used two broad variables namely Corporate Social Responsibility (CSR) and Corporate Social Irresponsibility (CSIR). CSR has 15 manifest (observed) variables while CSIR has 12 manifest variables (items). The responses for each manifest variable from 48 subjects were collected from the field. The responses were based on five-point likert scale i.e., 1=Strongly Disagree, 2=Disagree, 3=Neutral, 4=Agree and 5=Strongly Agree.

\section{Descriptive Statistics}

Descriptive statistics summarizes basic information for each manifest variable regarding a measure of central tendency (mean) and a measure of dispersion (standard deviation). The descriptive statistics for each manifest variable was measured on a five-point likert scale. This scale indicates the respondent's agreement or disagreement with the statement. Option 1 and option 2 denoted 
INTERNATIONAL JOURNAL OF ACADEMIC RESEARCH IN BUSINESS AND SOCIAL SCIENCES

Vol. 8, No. 9, Sept. 2018, E-ISSN: 2222-6990 @ 2018 HRMARS

respondent's degree of disagreement with the statement. Option 3 indicated that a respondent is neutral or indifferent with the statement while option 4 and option 5 indicated respondent's degree of agreement with the statement. Consider table 4.1 and table 4.2 below:

Table 4.1: Summary Statistics (Corporate Social Responsibility)

\begin{tabular}{r|rrrrr} 
Variable & Obs & Mean & Std. Dev. & Min & Max \\
\hline csr01 & 48 & 3.208333 & .988408 & 1 & 5 \\
$\operatorname{csr02}$ & 48 & 3.166667 & 1.117241 & 1 & 5 \\
$\operatorname{csr03}$ & 48 & 2.604167 & 1.026035 & 1 & 5 \\
$\operatorname{csr04}$ & 48 & 2.895833 & .9280403 & 1 & 5 \\
$\operatorname{csr05}$ & 48 & 3.270833 & .8929888 & 1 & 5 \\
& & & & & 5 \\
$\operatorname{csr06}$ & 48 & 3.145833 & .9890805 & 1 & 5 \\
$\operatorname{csr07}$ & 48 & 3.395833 & .7362811 & 2 & 5 \\
$\operatorname{csr08}$ & 48 & 3.229167 & .8809952 & 1 & 5 \\
$\operatorname{csr09}$ & 48 & 3.041667 & .988408 & 1 & 5 \\
$\operatorname{csr10}$ & 48 & 2.916667 & 1.048471 & 1 & 5 \\
& & & & & 5 \\
$\operatorname{csr11}$ & 48 & 3.208333 & .8981857 & 1 & 5 \\
$\operatorname{csr12}$ & 48 & 2.916667 & 1.107678 & 1 & 5 \\
$\operatorname{csr13}$ & 48 & 3.145833 & .9673298 & 1 & 5 \\
$\operatorname{csr14}$ & 48 & 3.1875 & .8910011 & 1 & 5 \\
$\operatorname{csr15}$ & 48 & 3.270833 & .7067933 & 2 & 5 \\
& & & & &
\end{tabular}

Source: Researcher's Field Data Analysis, 2018.

Table 4.1 above shows descriptive statistics for all 15 manifest variables regarding corporate social responsibility for all 48 subjects who have been questioned. It can be seen that most of the mean scores for responses were neutral and four items showed low disagreement. This indicates that on average most of the respondents are less aware about corporate social responsibility. 
INTERNATIONAL JOURNAL OF ACADEMIC RESEARCH IN BUSINESS AND SOCIAL SCIENCES

Vol. 8, No. 9, Sept. 2018, E-ISSN: 2222-6990 @ 2018 HRMARS

Table 4.2: Summary Statistics (Corporate Social Irresponsibility)

\begin{tabular}{r|rrrrr} 
Variable & Obs & Mean & Std. Dev. & Min & Max \\
\hline csir01 & 48 & 3.041667 & .8240619 & 1 & 5 \\
csir02 & 48 & 2.458333 & 1.009705 & 1 & 5 \\
csir03 & 48 & 2.583333 & 1.048471 & 1 & 5 \\
csir04 & 48 & 3.208333 & .7425755 & 1 & 5 \\
$\operatorname{csir05}$ & 48 & 3.270833 & .7067933 & 2 & 5 \\
\hline $\operatorname{csir06}$ & 48 & 2.979167 & .9106832 & 1 & 5 \\
$\operatorname{csir07}$ & 48 & 2.645833 & .956269 & 1 & 5 \\
$\operatorname{csir08}$ & 48 & 2.9375 & .9318536 & 1 & 5 \\
$\operatorname{csir09}$ & 48 & 3.104167 & .8809952 & 1 & 5 \\
$\operatorname{csir} 10$ & 48 & 2.5625 & 1.049949 & 1 & 5 \\
\hline $\operatorname{csir11}$ & 48 & 2.75 & .9339917 & 1 & 5 \\
$\operatorname{csir} 12$ & 48 & 2.6875 & 1.013867 & 1 & 5
\end{tabular}

Source: Researcher's Field Data Analysis, 2018.

Table 4.2 above indicates descriptive statistics for all 12 manifest variables regarding corporate social irresponsibility for all 48 subjects who have been questioned. It can be seen that most of the mean scores for the responses showed low disagreement while others showed neutrality with the statements. This indicates that to some extent on average most of the respondents are aware about corporate social irresponsibility.

\section{Correlation Anaysis}

Correlation measures a linear association (relationship) between a pair of variables. The correlation matrix (R-matrix) provides Pearson's correlation coefficients for each pair of variables. This correlation coefficient ranges between -1 and +1 while values closer to +1 and -1 are considered to have strong relationship either positively or negatively respectively. Values which are closer to zero indicate weak linear relationship between the variables. However, there is a multicollinearity problem that may exist when variables have very strong relationship of 0.9 and above. This problem hinders factor analysis to determine unique factors. Multicollinearity can be detected by looking at the determinant of the R-matrix. The benchmark for the absence of multicollinearity problem in the correlation matrix is $\mathbf{0 . 0 0 0 0 1}$, less than that there will be a problem of extreme multicollinearity in our data. Elimination of highly correlated variables is the solution for this problem at early stages. Also perfect correlation of the variables leads to singularity problem. 
INTERNATIONAL JOURNAL OF ACADEMIC RESEARCH IN BUSINESS AND SOCIAL SCIENCES

Vol. 8, No. 9, Sept. 2018, E-ISSN: 2222-6990 @ 2018 HRMARS

Table 4.3: CSR Correlation Matrix

\begin{tabular}{|c|c|c|c|c|c|c|c|c|c|c|}
\hline & $\operatorname{csr} 01$ & $\operatorname{csr} 02$ & csro3 & $\operatorname{csr} 04$ & csro5 & $\operatorname{csr} 06$ & $\operatorname{csr} 07$ & $\operatorname{csr} 08$ & $\operatorname{csr} 09$ & $\operatorname{csr} 10$ \\
\hline $\operatorname{csr} 01$ & 1.0000 & & & & & & & & & \\
\hline $\operatorname{csr} 02$ & 0.6037 & 1.0000 & & & & & & & & \\
\hline $\operatorname{csr} 03$ & 0.5026 & 0.2444 & 1.0000 & & & & & & & \\
\hline $\operatorname{csr} 04$ & 0.2561 & 0.0787 & 0.4697 & 1.0000 & & & & & & \\
\hline $\operatorname{csr} 05$ & 0.2481 & 0.1457 & 0.2124 & 0.2915 & 1.0000 & & & & & \\
\hline $\operatorname{csr} 06$ & 0.4471 & 0.4974 & 0.3516 & -0.0295 & 0.2434 & 1.0000 & & & & \\
\hline $\operatorname{csr} 07$ & 0.2936 & 0.2543 & 0.2681 & 0.0305 & 0.4483 & 0.4157 & 1.0000 & & & \\
\hline $\operatorname{csr} 08$ & 0.4327 & 0.1333 & 0.2202 & 0.0298 & 0.1899 & 0.3271 & 0.2836 & 1.0000 & & \\
\hline $\operatorname{csr} 09$ & 0.4701 & 0.3404 & 0.3942 & 0.0976 & 0.2039 & 0.4942 & 0.2107 & 0.4286 & 1.0000 & \\
\hline $\operatorname{csr} 10$ & 0.2840 & 0.3027 & 0.4829 & 0.0128 & 0.2746 & 0.5044 & 0.2090 & 0.2284 & 0.5167 & 1.0000 \\
\hline $\operatorname{csr} 11$ & 0.3335 & 0.2615 & 0.1837 & 0.0776 & 0.2730 & 0.5159 & 0.3874 & 0.2073 & 0.3255 & 0.2899 \\
\hline $\operatorname{csr} 12$ & 0.4243 & 0.3381 & 0.4571 & 0.1777 & 0.4105 & 0.4580 & 0.3805 & 0.1944 & 0.4308 & 0.6351 \\
\hline $\operatorname{csr} 13$ & 0.3904 & 0.3314 & 0.3810 & 0.0173 & 0.1257 & 0.4443 & 0.0666 & 0.5591 & 0.4608 & 0.4318 \\
\hline $\operatorname{csr} 14$ & 0.4379 & 0.3099 & 0.2924 & -0.1045 & 0.0685 & 0.5719 & 0.2736 & 0.4862 & 0.2809 & 0.3815 \\
\hline \multirow[t]{2}{*}{$\operatorname{csr} 15$} & 0.3439 & 0.2649 & 0.0923 & 0.1412 & -0.0176 & 0.1858 & 0.1167 & 0.3424 & 0.2881 & -0.0837 \\
\hline & $\operatorname{csr} 11$ & $\operatorname{csr} 12$ & $\operatorname{csr} 13$ & $\operatorname{csr} 14$ & $\operatorname{csr} 15$ & & & & & \\
\hline $\operatorname{csr} 11$ & 1.0000 & & & & & & & & & \\
\hline $\operatorname{csr} 12$ & 0.3386 & 1.0000 & & & & & & & & \\
\hline $\operatorname{csr} 13$ & 0.2826 & 0.3293 & 1.0000 & & & & & & & \\
\hline $\operatorname{csr} 14$ & 0.4287 & 0.1671 & 0.4366 & 1.0000 & & & & & & \\
\hline $\operatorname{csr} 15$ & 0.1103 & 0.2197 & 0.3456 & 0.0528 & 1.0000 & & & & & \\
\hline
\end{tabular}

Source: Researcher's Field Data Analysis, 2018.

Table 4.3 above indicates various interrelationships among the manifest variables concerning corporate social responsibility. It can be seen that no variables are highly correlated that can pose a problem of extreme multicollinearity in our analysis.

Table 4.4: Determinant, KMO and Bartlett's Test for CSR

\begin{tabular}{|c|c|c|}
\hline \multicolumn{2}{|c|}{$\begin{array}{l}\text { Determinant (R matrix) } \\
\text { Kaiser-Meyer-Olkin Measure of Sampling } \\
\text { Adequacy (Overall). }\end{array}$} & $\begin{array}{r}0.001 \\
0.721 \\
285.074 \\
105 \\
0.000\end{array}$ \\
\hline
\end{tabular}

Source: Researcher's Field Data Analysis, 2018.

The determinant at table 4.4 confirms that the above correlation matrix (table 4.3) does not face the problem of singularity and extreme multicollinearity since its value of 0.001 is greater than the benchmark value of 0.00001 . Thus, all statements correlate fairly and considering elimination of variables is not necessary at this stage.

Kaiser-Meyer-Olkin (KMO) is a measure of sampling adequacy. It ranges between 0 and 1 . A value closer to 0 indicates that our factor model will be inappropriate while a value closer to 1 will indicate our factor model is suitable (correct). Thus, factors analysis will lead to clearly different and reliable factors. Kaiser (1974) suggested that KMO values greater than 0.5 are acceptable otherwise more 
INTERNATIONAL JOURNAL OF ACADEMIC RESEARCH IN BUSINESS AND SOCIAL SCIENCES

Vol. 8, No. 9, Sept. 2018, E-ISSN: 2222-6990 @ 2018 HRMARS

sample data should be collected. In our case the KMO value is 0.721 which is good and we are confident that our factor analysis model is correct for these data regarding corporate social responsibility.

Bartlett's test of sphericity tests whether our correlation matrix is an identity matrix. For an identity matrix we mean that each pair of variables indicates zero correlation. Thus for factor analysis to be applicable we need to reject this hypothesis. The null hypothesis is rejected when the probability value is less than 0.05 . This will ensure that there are some relationships of variables in our data. Thus, it can be seen that the test provided a probability significance value of 0.000 thus rejecting the null hypothesis of identity matrix for our correction matrix. Thus, factor analysis will be applicable for our data regarding corporate social responsibility.

Table 4.5: CSIR Correlation Matrix (Matrix R)

\begin{tabular}{|c|c|c|c|c|c|c|c|c|c|c|}
\hline & csir01 & $\operatorname{csir} 02$ & csir03 & csir04 & csir05 & $\operatorname{csir} 06$ & csir07 & csir08 & csir09 & $\operatorname{csir} 10$ \\
\hline csir01 & 1.0000 & & & & & & & & & \\
\hline csir02 & 0.2323 & 1.0000 & & & & & & & & \\
\hline csir03 & 0.3407 & 0.6465 & 1.0000 & & & & & & & \\
\hline $\operatorname{csir04}$ & 0.5418 & 0.2388 & 0.4691 & 1.0000 & & & & & & \\
\hline $\operatorname{csir} 05$ & 0.3820 & 0.1503 & 0.1555 & 0.4172 & 1.0000 & & & & & \\
\hline $\operatorname{csir} 06$ & 0.4548 & 0.0800 & 0.3472 & 0.2268 & 0.4717 & 1.0000 & & & & \\
\hline csir07 & -0.2509 & -0.2249 & -0.1715 & -0.3134 & -0.1699 & 0.0646 & 1.0000 & & & \\
\hline $\operatorname{csir} 08$ & 0.3637 & 0.5060 & 0.5390 & 0.3882 & 0.2524 & 0.1990 & -0.3835 & 1.0000 & & \\
\hline csir0g & 0.1111 & -0.0070 & -0.2054 & -0.0339 & -0.1488 & -0.3155 & -0.2583 & -0.1992 & 1.0000 & \\
\hline $\operatorname{csir} 10$ & -0.4457 & 0.0326 & -0.0338 & -0.5083 & -0.5824 & -0.3213 & 0.2874 & -0.2895 & 0.2113 & 1.0000 \\
\hline $\operatorname{csir} 11$ & 0.3455 & 0.5753 & 0.6953 & 0.4141 & 0.1047 & 0.2689 & -0.3156 & 0.5195 & -0.1228 & -0.0488 \\
\hline \multirow[t]{2}{*}{$\operatorname{csir} 12$} & 0.2706 & 0.7041 & 0.5955 & 0.3144 & 0.0315 & 0.2463 & -0.0946 & 0.3392 & 0.0610 & 0.0087 \\
\hline & csir11 & $\operatorname{csir} 12$ & & & & & & & & \\
\hline $\operatorname{csir} 11$ & 1.0000 & & & & & & & & & \\
\hline $\operatorname{csir} 12$ & 0.5673 & 1.0000 & & & & & & & & \\
\hline
\end{tabular}

Source: Researcher's Field Data Analysis, 2018.

Table 4.5 above presents various correlations among the manifest variables concerning corporate social irresponsibility. It can be seen that no variables are highly correlated that can pose a problem of extreme multicollinearity in our analysis. 
INTERNATIONAL JOURNAL OF ACADEMIC RESEARCH IN BUSINESS AND SOCIAL SCIENCES

Vol. 8, No. 9, Sept. 2018, E-ISSN: 2222-6990 @ 2018 HRMARS

Table 4.6: Determinant, KMO and Bartlett's Test for CSIR

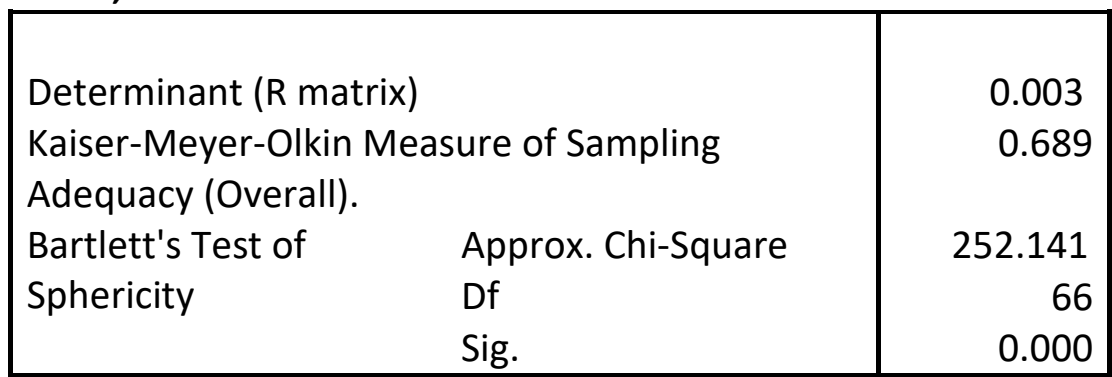

Source: Researcher's Field Data Analysis, 2018.

The determinant at table 4.6 confirms that the above correlation matrix (table 4.5) does not face the problem of singularity and extreme multicollinearity since its value of 0.003 is greater than the benchmark value of 0.00001 . Thus, all statements correlate fairly and considering elimination of variables is not necessary at this stage. Our KMO value of 0.689 is good indicating that our factor model is appropriate for these data concerning corporate social irresponsibility. The Bartlett's test of sphericity provided significant results indicating that our factor model is also appropriate.

\section{Reliability Measure of Variables}

In this study we are more concerned about inter-item reliability which measures the internal consistency of the data. This explains how items in our data are correlated with each other to describe a particular concept or construct. The Cronbach's alpha coefficient has been adopted to measure the internal consistency reliability in this study. Cronbach's values greater than 0.5 are considered to be acceptable, however values greater than 0.7 are highly recommended to indicate more reliability (Pallant, 2001).

Table 4.7: Cronbach's Alpha Reliability Measure for CSR (All items)

Test scale $=$ mean (unstandardized items)

\begin{tabular}{|c|c|c|c|c|c|c|}
\hline Item & abs & Sign & $\begin{array}{l}\text { item-test } \\
\text { correlation }\end{array}$ & $\begin{array}{l}\text { item-rest } \\
\text { correlation }\end{array}$ & $\begin{array}{c}\text { average } \\
\text { interitem } \\
\text { covariance }\end{array}$ & alpha \\
\hline csro1 & 48 & + & 0.7424 & 0.6818 & .2543255 & 0.8466 \\
\hline csr02 & 48 & + & 0.5982 & 0.5017 & .2633368 & 0.8566 \\
\hline csr03 & 48 & + & 0.6471 & 0.5669 & .2615833 & 0.8527 \\
\hline Csro 04 & 48 & + & 0.2901 & 0.1842 & .2958265 & 0.8712 \\
\hline csr05 & 48 & + & 0.4639 & 0.3741 & .2817688 & 0.8622 \\
\hline $\operatorname{csr} 06$ & 48 & + & 0.7388 & 0.6775 & .2546177 & 0.8468 \\
\hline $\operatorname{csr} 07$ & 48 & + & 0.5088 & 0.4392 & .2826163 & 0.8593 \\
\hline $\operatorname{csr} 08$ & 48 & + & 0.5602 & 0.4815 & .2742382 & 0.8572 \\
\hline $\operatorname{csr} 09$ & 48 & + & 0.6854 & 0.6147 & .2595082 & 0.8502 \\
\hline $\operatorname{csr} 10$ & 48 & + & 0.6501 & 0.5684 & .2604727 & 0.8526 \\
\hline csr11 & 48 & + & 0.5653 & 0.4855 & .273264 & 0.8570 \\
\hline csr12 & 48 & + & 0.6956 & 0.6171 & .2536922 & 0.8497 \\
\hline $\operatorname{csr} 13$ & 48 & + & 0.6426 & 0.5668 & .2642039 & 0.8528 \\
\hline $\operatorname{csr} 14$ & 48 & + & 0.5773 & 0.4996 & .2725138 & 0.8563 \\
\hline $\operatorname{csr} 15$ & 48 & + & 0.3634 & 0.2869 & .2929916 & 0.8649 \\
\hline Test $s$ & & & & & .269664 & 0.8643 \\
\hline
\end{tabular}


INTERNATIONAL JOURNAL OF ACADEMIC RESEARCH IN BUSINESS AND SOCIAL SCIENCES Vol. 8, No. 9, Sept. 2018, E-ISSN: 2222-6990 @ 2018 HRMARS

The overall Cronbach's alpha coefficient of 0.8643 in the above table 4.7 indicates a high degree of internal consistency for all manifest variables regarding corporate social responsibility. Also, it can be seen that all items are worth to be retained at this stage for further analysis. It can be seen from the last column (alpha) that removing any item from the scale would not lead to any significant increase in Cronbach's alpha.

Table 4.8: Cronbach's Reliabilty Measure for CSIR (All items)

Test scale $=$ mean (unstandardized items)

\begin{tabular}{|c|c|c|c|c|c|c|}
\hline Item & $\mathrm{Obs}$ & Sign & $\begin{array}{l}\text { item-test } \\
\text { correlation }\end{array}$ & $\begin{array}{c}\text { item-rest } \\
\text { correlation }\end{array}$ & $\begin{array}{c}\text { average } \\
\text { interitem } \\
\text { covariance }\end{array}$ & alpha \\
\hline csir01 & 48 & + & 0.6282 & 0.5409 & .2360654 & 0.8040 \\
\hline csir02 & 48 & + & 0.6433 & 0.5364 & .2268133 & 0.8032 \\
\hline csir03 & 48 & + & 0.7592 & 0.6757 & .2110977 & 0.7893 \\
\hline csir0 4 & 48 & + & 0.6757 & 0.6052 & .2356141 & 0.8007 \\
\hline csir0 5 & 48 & + & 0.5192 & 0.4322 & .2504594 & 0.8127 \\
\hline $\operatorname{csir} 06$ & 48 & + & 0.5388 & 0.4267 & .2419649 & 0.8127 \\
\hline csir0 7 & 48 & - & 0.4169 & 0.2833 & .2542956 & 0.8250 \\
\hline $\operatorname{csir} 08$ & 48 & + & 0.7186 & 0.6366 & .2217037 & 0.7946 \\
\hline csir09 & 48 & - & 0.2549 & 0.1214 & .2721712 & 0.8358 \\
\hline $\operatorname{csir} 10$ & 48 & - & 0.5073 & 0.3711 & .2420132 & 0.8189 \\
\hline $\operatorname{csir} 11$ & 48 & + & 0.7256 & 0.6449 & .2208333 & 0.7939 \\
\hline $\operatorname{csir} 12$ & 48 & + & 0.6092 & 0.4951 & .2306979 & 0.8070 \\
\hline Test scale & & & & & .2369775 & 0.8219 \\
\hline
\end{tabular}

Source: Researcher's Field Data Analysis, 2018.

Table 4.8 above presents the Cronbach's alpha for each manifest variable regarding corporate social irresponsibility. It can be seen that all items are useful to be retained at this stage for further analysis. The overall Cronbach's alpha coefficient is 0.8219 indicating a high degree of reliability on all observed variables concerning corporate social irresponsibility. It can be seen that Cronbach alpha would not increase substantially by deleting any item from the scale.

\section{Exploratory Factor Analysis (EFA)}

Factor analysis is a multivariate statistical technique for data reduction. In factor analysis we want to determine latent variable(s) (factors) through examining observed (manifest) variables which imply the existence of that particular hidden factor(s). Factor analysis is useful in identifying underlying factors. In a theory of factor analysis it is assumed that the observed variables are correlated due to their dependency on one or more of the same hidden variables (i.e. factors). So in general, factor analysis compresses sets of complex data without losing data integrity, to form reduced set of factors, which are assumed to represent the observed variables under consideration. It eliminates duplication from a set of correlated observed variables. Observed variables which are correlated are clustered 
together into various independent sets of homogeneous items which will create new variables known as factors. The derived factors are relatively independent from one another i.e. factors are not correlated with one another. In EFA, the researcher has no prior idea about how many factors there are and where there are zero loadings.

In this study, the principal-component exploratory factor analysis with the support of statistical package STATA 11.0 has been adopted. The two sets of exploratory factor analysis were performed regarding corporate social responsibility and corporate social irresponsibility. The Kaiser criterion (egein-values greater than one as cut-off) was used to retain essential factors during the process of factor extraction. By eigen-value we mean the amount of variance in the data that has been described by the factor. The sum of eigen-values is equal to the number of items in the scale.

In the process of conducting EFA, several rounds were performed so as to obtain a "clean" final solution. In each round of factor analysis it was inexorable to delete various manifest variables due to low communality (high uniqueness) estimates within the factor space and lack of simple structure ( the presence of item(s) which cross-loaded into more than one factor). Communality measures the proportion of variance of the manifest variable that has been explained by the factor. It ranges between 0 and 1 . The remaining proportion of variance which has not been explained by the factor is called uniqueness. The item with high communality (low uniqueness) is preferable. Otherwise it can be removed from the scale.

So to obtain the final solution which has a simple structure, the items were retained if the factor loadings were 0.4 and above. A factor loading measures the correlation (relationship) between a manifest variable (item) and a factor. So, if the factor loadings of the items across factors were less than $\mathbf{0 . 4}$, they were scored out of the scale since they are thought to be cross-loaded. All items that did not meet these inclusion criteria were discarded and the process was repeated until a clean final solution with simple structure was achieved.

For the purpose of good factor solution interpretability, factor rotation was performed using varimax rotation without Kaiser Normalization. The varimax rotation leaves the derived factors to be uncorrelated (independent). Finally, the items comprising the factors were scrutinized and the items with the highest loadings were the basis for factor labeling.

The final rotated solutions and final Cronbach's alpha for both cases i.e. corporate social responsibility and corporate social irresponsibility are presented in tables below:

\section{Table 4.9: Final Rotated Solution for CSR}

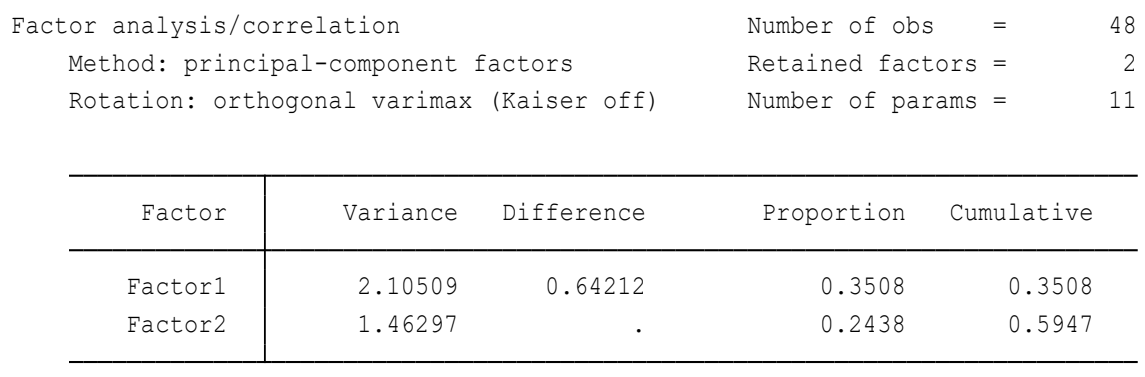

LR test: independent vs. saturated: $\operatorname{chi2}(15)=59.92$ Prob $>$ chi2 $=0.0000$

Source: Researcher's Field Data Analysis, 2018. 
INTERNATIONAL JOURNAL OF ACADEMIC RESEARCH IN BUSINESS AND SOCIAL SCIENCES Vol. 8, No. 9, Sept. 2018, E-ISSN: 2222-6990 @ 2018 HRMARS

Table 4.9 above presents the final rotated factor solution regarding corporate social responsibility. Regarding the Eigen-value criterion and other inclusion criteria, it can be seen that only two significant factors were retained after performing successive rounds of EFA. The two factors accounted for $59.47 \%$ of the total variance in our data.

Table 4.10: Final Rotated Loadings for CSR

\begin{tabular}{r|ll|l}
\hline Variable & Factor1 & Factor2 & Uniqueness \\
\hline $\operatorname{csr07}$ & 0.5501 & & 0.5664 \\
$\operatorname{csr08}$ & & 0.7118 & 0.4341 \\
$\operatorname{csr10}$ & 0.8436 & & 0.2708 \\
$\operatorname{csr11}$ & 0.5982 & & 0.5825 \\
$\operatorname{csr12}$ & 0.8176 & & 0.3063 \\
$\operatorname{csr15}$ & & 0.8502 & 0.2718 \\
\hline
\end{tabular}

Source: Researcher's Field Data Analysis, 2018.

Table 4.10 above indicates the final rotated factor loadings for corporate social responsibility. The factors loading less than 0.4 were considered to be less significant so they were not displayed in our table. This has been done for the purpose of easy and clear interpretation of the rotated solution. It can be seen that items csr07, csr10, csr11, csr12 have loaded strongly on factor 1 while items csr08, csr15 have loaded strongly on factor 2 . The remaining items did not meet the inclusion criteria did not meet the inclusion criteria so they were deleted during the EFA process. Thus, we label factor 1 as Corporate Support and factor 2 is labeled as Corporate Geniality.

Table 4.11: Final Cronbach's Alpha for CSR

\begin{tabular}{|l|l|l|}
\hline \multicolumn{1}{|c|}{ Factor } & \multicolumn{1}{|c|}{ Items } & \multicolumn{1}{|c|}{$\begin{array}{c}\text { Cronbach Alpha } \\
\text { Coefficient }\end{array}$} \\
\hline Corporate Support & csr07, csr10, csr11, csr12 & 0.7072 \\
\hline Corporate Geniality & csr08, csr15 & 0.5010 \\
\hline
\end{tabular}

Source: Researcher's Field Data Analysis, 2018.

It can be seen form table 4.11 above that the final reliability measure showed significant results since the Cronbach's alpha coefficient for each factor is relatively acceptable. Thus indicating internal consistency of the retained items in each factor they belong. So, the corporate social responsibility is influenced by corporate support and corporate geniality. 
INTERNATIONAL JOURNAL OF ACADEMIC RESEARCH IN BUSINESS AND SOCIAL SCIENCES

Vol. 8, No. 9, Sept. 2018, E-ISSN: 2222-6990 @ 2018 HRMARS

On the other hand, the principal-component exploratory factor analysis regarding corporate social irresponsibility obtained the following results:

Table 4.12: Final Rotated Solution for CSIR

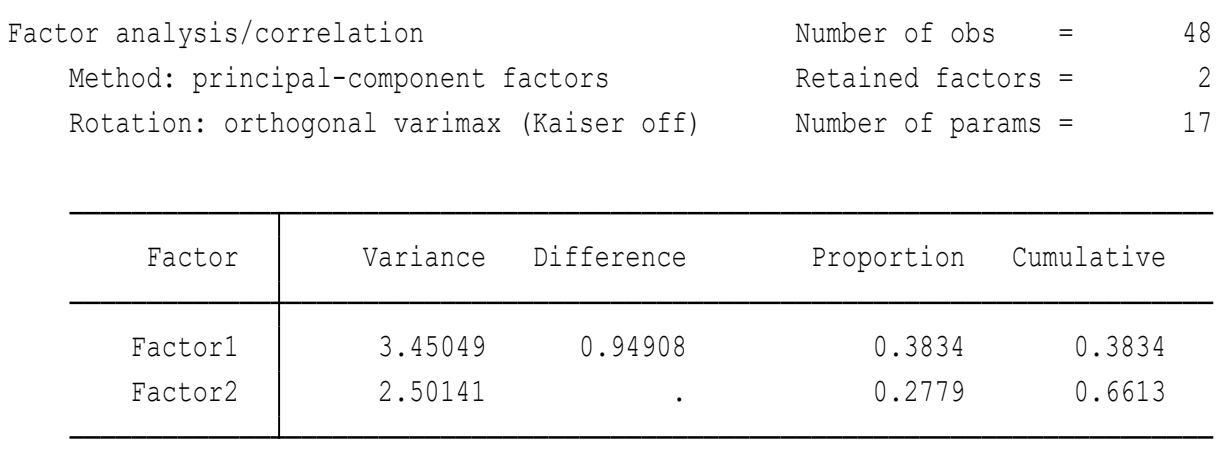

LR test: independent vs. saturated: $\operatorname{chi2}(36)=190.37$ Prob>chi2 $=0.0000$

Source: Researcher's Field Data Analysis, 2018.

Table 4.12 above provides the final rotated factor solution regarding corporate social irresponsibility. Regarding the Eigen-value criterion and other inclusion criteria, it can be seen that only two essential factors were retained after performing continuous rounds of EFA. The two factors accounted for $66.13 \%$ of the total variance in our data.

Table 4.13: Final Rotated Factor Loadings for CSIR

Rotated factor loadings (pattern matrix) and unique variances

\begin{tabular}{c|cc|c}
\hline Variable & Factor1 & Factor2 & Uniqueness \\
\hline Csir01 & & 0.6727 & 0.4425 \\
Csir02 & 0.8516 & & 0.2747 \\
Csir03 & 0.8559 & & 0.2437 \\
Csir04 & & 0.7033 & 0.3550 \\
Csir05 & & 0.7793 & 0.3921 \\
Csir08 & 0.6157 & & 0.4798 \\
$\operatorname{Csir10}$ & & -0.8737 & 0.2287 \\
$\operatorname{csir11}$ & 0.8236 & & 0.3032 \\
$\operatorname{csir12}$ & 0.8193 & & 0.3285 \\
\hline
\end{tabular}

(blanks represent abs (loading) <.4)

Source: Researcher's Field Data Analysis, 2018.

Table 4.13 above gives out the final rotated factor loadings for corporate social responsibility. For the purpose of easy and clear interpretation of the rotated solution, the factors loading less than 0.4 were considered to be less significant so they were not displayed in our table. The table illustrates that items csir02, csir03, csir08, csir11 and csir12 have loaded strongly on factor 1 while items csir01, csir04, csir05, and csir10 have loaded strongly on factor 2. The remaining items did not meet the inclusion criteria so they were discarded during the EFA process. Thus, we label factor 1 as Corporate Environmental Management and factor 2 is labeled as Corporate Safety Management. 
INTERNATIONAL JOURNAL OF ACADEMIC RESEARCH IN BUSINESS AND SOCIAL SCIENCES

Vol. 8, No. 9, Sept. 2018, E-ISSN: 2222-6990 @ 2018 HRMARS

Table 4.14: Final Cronbach's Alpha for CSIR

\begin{tabular}{|l|l|l|}
\hline \multicolumn{1}{|c|}{ Factor } & \multicolumn{1}{|c|}{ Items } & \multicolumn{1}{|c|}{$\begin{array}{c}\text { Cronbach Alpha } \\
\text { Coefficient }\end{array}$} \\
\hline $\begin{array}{l}\text { Corporate Environm`ental } \\
\text { Management }\end{array}$ & $\begin{array}{l}\text { csir02, csir03, csir08, csir11, } \\
\text { csir12 }\end{array}$ & 0.8690 \\
\hline $\begin{array}{l}\text { Corporate Safety } \\
\text { Management }\end{array}$ & csir01, csir04, csir05, csir10 & 0.7785 \\
\hline
\end{tabular}

\section{Source: Researcher's Field Data Analysis, 2018.}

It can be seen form table 4.14 above that the final reliability measure showed significant results since the Cronbach's alpha coefficient for each factor is relatively good. Thus indicating internal consistency of the retained items in each factor they belong. So, the corporate seem to participate in environmental management and safety management.

\section{Demographic Information}

In a nutshell, this sub-section presents the summary statistics for demographic information of the respondents. It takes into account the gender of the respondents, the age group of the respondent, respondent's position in the organization, respondent's stakeholder ship and the favorite drink of the respondent. Consider table 4.15 below:

Table 4.15: Respondents' Demographic Information

\begin{tabular}{|c|c|c|c|c|c|}
\hline Demographics & Label & Frequency & Percentage (\%) & Mean & Standard Deviation \\
\hline \multirow[t]{3}{*}{ Gender } & Male & 31 & 64.58 & & \\
\hline & Female & 17 & 35.42 & & \\
\hline & Total & 48 & 100 & 1.64 & 0.48 \\
\hline \multirow[t]{6}{*}{ Age Group } & $18-29$ yrs & 18 & 37.50 & & \\
\hline & $30-41$ yrs & 22 & 45.83 & & \\
\hline & $42-53$ yrs & 08 & 16.67 & & \\
\hline & $54-65$ yrs & 00 & 0.00 & & \\
\hline & Above 65 yrs & 00 & 0.00 & & \\
\hline & Total & 48 & 100 & 1.79 & 0.71 \\
\hline \multirow[t]{4}{*}{ Respondent's Position in Organization } & Customer & 14 & 29.17 & & \\
\hline & Local Community & 17 & 35.42 & & \\
\hline & Employee & 17 & 35.42 & & \\
\hline & Total & 48 & 100 & 2.06 & 0.80 \\
\hline \multirow[t]{4}{*}{ Respondent's Stakeholdership } & Employee & 18 & 37.50 & & \\
\hline & Customer & 15 & 31.25 & & \\
\hline & Local Community & 15 & 31.25 & & \\
\hline & Total & 48 & 100 & 1.93 & 0.83 \\
\hline \multirow[t]{9}{*}{ Respondent's Favorite Drink } & Beer & 14 & 29.17 & & \\
\hline & Spirit & 04 & 8.33 & & \\
\hline & Wine & 04 & 8.33 & & \\
\hline & Mineral & 02 & 4.17 & & \\
\hline & Soda & 12 & 25.00 & & \\
\hline & Natural Juice & 07 & 14.58 & & \\
\hline & Manufactured Juice & 03 & 6.25 & & \\
\hline & Traditional Drinks & 02 & 4.17 & & \\
\hline & Total & 48 & 100 & 3.77 & 2.27 \\
\hline
\end{tabular}


INTERNATIONAL JOURNAL OF ACADEMIC RESEARCH IN BUSINESS AND SOCIAL SCIENCES Vol. 8, No. 9, Sept. 2018, E-ISSN: 2222-6990 @ 2018 HRMARS

Source: Researcher's Field Data Analysis, 2018.

From the table 4.15 above it can be seen that most of the respondents in this study were male accounted for $64.58 \%$ of the total respondents. Also it can be observed that about $45.83 \%$ of the total respondents were in the age group between $30 \mathrm{yrs}$ and $41 \mathrm{yrs}$. Most of the employees and people from the local community were questioned however, employees formed a larger group as stakeholders about $37.5 \%$ of the total respondents. Also about $29.17 \%$ of the total respondents favor to drink beer while about $25 \%$ and $14.58 \%$ prefer to drink soda and natural juice respectively.

\section{Managerial Implication and Conclusion \\ Conclusion}

Generally, the society regards social responsibility as a centerpiece of any corporate. It is through the social responsibility that the company can produce outcomes which are socially desirable. Thus, the key purpose of this study was to examine the perceptions of the stakeholders regarding social responsibility and social irresponsibility practices of the beverage company in Tanzania. The primary data was collected from 48 subjects regarding their perceptions on social responsibility and social irresponsibility of various beverage companies producing soft drinks and hard drinks (alcohols). In this study, stakeholders were categorized as employee, customer and a local community.

The researcher adopted exploratory factor analysis methodology to extract important factors which attributed to company's social responsibility and social irresponsibility. All manifest variables were correlated and factor models found to be appropriate based on KMO measure of sampling adequacy and Bartlett's measure of sphericity. The KMO values for corporate social responsibility and corporate social irresponsibility were 0.721 and 0.689 respectively. Also a measure of reliability (Cronbach's Alpha) indicated that all variables were internally consistent regarding corporate social responsibility and corporate social irresponsibility. Cronbach's values for corporate social responsibility and corporate social irresponsibility were 0.8643 and 0.8219 respectively.

Two sets of exploratory factor analysis were applied and only factors which met Eigen-value of greater than one criterion were extracted. Varimax rotation was used to rotate the factor solution so as to easy interpretation of the final solution. The process of factor analysis was repeated until a clean final solution which has a simple structure was obtained.

Regarding corporate social responsibility, the final factor solution suggested only two factors namely, Corporate Support and Corporate Geniality, while for the case of corporate social irresponsibility also only two factors were suggested by the final solution namely Corporate Environmental Management and Corporate Safety Management. The reliability measure for each factor indicated significant results thus indicating that all retained variables were internally consistent regarding the factors they belong to. Corporate support and corporate geniality seem to influence company's social responsibility while the company also seems to participate in environmental management and safety management.

\section{Recommendetions}

From the finding we can see that social responsibility is the fundamental element for any succeeded company in the eyes of the society. Producing socially desirable outcomes must be the central goal of each company. In this study we found that corporate social responsibility is influenced by 
corporate support and corporate geniality. The company should always create a good image to their employees and to the rest of the society it surrounds. This good image can be created through a good relationship between the company and the employee and/or society. This can be pursued by providing a good treatment to all stakeholders and take into consideration their opinions. The company should also provide assistance to the employees who are in need of support. Also the company will be socially responsible by serving the community through providing roads, hospitals, water etc.

It should always be noted that production is always associated with negative externalities such as pollution. The company should always compensate the society which is affected by pollution. This will tend to increase the social benefit and reduce social cost. Customer and employee discrimination should also be avoided so as to eliminate strata in the company and society. The seminars regarding safety measures should also be provided by the company to all stakeholders so as to create awareness on how the employees and society can protect themselves against unexpected events. Therefore, social responsibility can be considered to be the cornerstone of every company which needs to win the trust of the society. The company should always adhere to ethics and moral standards of the community so as to produce outcomes which are socially desirable.

From the study, researchers believe the community, employees, stakeholders and the government through the knowledge imposed will be very much benefited. And gradually environmental pollution and social irresponsibility activities will disappear and make the world a better place for future generation.

\section{References}

1. Amstrong, .J. S., (1977), Social Irresponsibility in Management: Journal of business research.

2. Baucus, M. and Baucus, D. (1997). 'Paying the piper: an empirical examination of longer term financial consequences for illegal corporate behaviour', Academy of Management Journal, 40, pp. 129-151.

3. Bowen, H. (1953). Social responsibility of the businessman. Harper and Row, New York

4. Bowmann-Larsen, L and Wiggen, O., (2004). Responsibility in World Business: Managing harmful side -effect of corporate activity. USA: United Nation University press.

5. Calo, R. (1974) The Boundaries of Privacy Harm. http://ilj.law.indiana.edu/articles/86/86 3 Calo.pdf. Retrieved on 26 September 2018

6. Caroll, A. B (1979). A three dimensional conceptual model of corporate performance, Academy of management review 4.

7. Davis, K. (1960). Can business afford to ignore corporate social responsibility? California Management Review, 2, 70-76.

8. Fort, T. L., (1999). The first man and the company man. The common good, transcendence and mediating institution, America business law journal

9. Freeman, R. E. (1984). Strategic management: A stakeholder approach. Pitman, Boston (MA)

10. Friedman, (1970). The social responsibility of business in to increase its profits. New York Times Magazines, 13 Sept., 32-33. 
INTERNATIONAL JOURNAL OF ACADEMIC RESEARCH IN BUSINESS AND SOCIAL SCIENCES Vol. 8, No. 9, Sept. 2018, E-ISSN: 2222-6990 @ 2018 HRMARS

11. Garriga, E. and Mele, D (2004). Corporate social responsibility theories: Mapping the territory journal of business ethics, Av Pearson 21 Barcelona.

12. Hopkins, M. (2004). Corporate social responsibility: An issue paper: Policy integration department World commission on the social dimension of globalization international labour office, Geneva

13. Kemp, D. (2003). Discovery participatory development through corporate NGO Collaboration: A mining industries case: Center for social responsibility in mining research. University of Queensland Australia.

14. Kotchen, M. J. and Moon, J. J (2011) Corporate Social Responsibility for Irresponsibility Working Paper Series. Retrieved on 26 September 2018, http://www.nber.org/papers/w17254

15. Kothari C. R (2004). Research Methodology: Methods and techniques $2^{\text {nd }}$ Revised Ed. Jaipur India

16. Kotler P. \& Armstrong G. 2006. Principles of marketing, (11th Ed.) Upper Saddle River: New Jersey: Prentice-Hall.

17. Leedy, P. and Ormrod, J. (2001). Practical research: Planning and design (7th ed.). Upper Saddle River, NJ: Merrill Prentice Hall. Thousand Oaks: SAGE Publications

18. Mele, D, (2002). Not only stakeholder interest the firm oriented toward the common good: University of Notre Dame press. Notre Dame

19. Mullin, L. J (2005). Management and Organisation Behaviour. $7^{\text {th }}$ Ed Pearson education limited, Essex, England.

20. Murray, K. B. and Vogel C. M, (1997). Using a hierarchy of effect approach to gauge the effective of corporate social responsibility to generate goodwill toward the firm: financial versus non-financial impact, journal of business research vol. 38

21. NEXEN CNOOC LTD, (2011). Building Residence responsibility: Social Responsibility Report.

22. O'Riordan, L. and Fairbrass, J. (2008). Corporate Social Responsibility (CSR): Models and Theories in Stakeholder Dialogue: Journal of Business Ethics Vol. 83, No. 4 (Dec., 2008), pp. 745-758

23. Pallant, J 2001, SPSS survival manual: a step by step to data analysis using SPSS, Allen \& Unwin, Australia

24. Pamler, A. and Hartely (2002). The Business Environment. McGrawHill, New York

25. Parmar, B.L., Freeman, R.E., Harrison, J.S., Wicks, A.C., Purnell, L. and De Colle, S. (2010) 'Stakeholder theory: the state of the art', The Academy of Management Annals, Vol. 4, No. 1, pp.403-445

26. Smith, N. C. (1999), "Ethics and the Typology of Consumer Value," in Consumer Value: A Framework for Analysis and Research, Morris B. Holbrook, Ed. New York: Rout ledge, 147- 58.

27. Wheelen, L. T and Hunger, D .J (2010). Strategic Management and Business Policy $12^{\text {th }}$ ed, Pearson education.

28. Wheelen, Thomas L., \& Hunger J. David (2010). Strategic Management and Business Policy (International Ed.). New York, NY: Prentice Hall Inc

29. William, C. (2010). Managing Effectively $4^{\text {th }}$ ed. Pearson eufin.org, (2009). Glossary, retrived 19 Dec 2012 from http://www.eufin.org/glossary,en41.html 
30. Wood D. J. (2010). Measuring Corporate Social Performances; A Review. International Journal of Management Review 12(1): 50-84

31. Wood, D.J. and R. Jones (1995). Stakeholder mismatching: a theoretical problem in empirical research on corporate social performance. The International Journal of Organizational Analysis, vol. 3, No. 3, pp. 229-267.

32. Wood. D. Jones. (2004) on Global Business Citizenship: Introduction to the Special Issue. Business and Society Review, 109 (1): 1-3.

33. Yassin N. (2016) Towards an Effective Multi-Stakeholder Consultation Process: Applying the Imagine Method in Context of Abu Dhabi's Education Policy. Springer science+ Business Media, New York. 